\title{
Üniversite Öğrencilerinin Mezuniyet Sonrası Kariyer Beklentileri: Ayvacık Meslek Yüksekokulu Örneği
}

\author{
Yasin Karadeniz ${ }^{\mathrm{a}, \mathrm{b}}$, Çiğgdem Özkan ${ }^{\mathrm{c}}$
}

\section{Özet}

$\mathrm{Bu}$ çalışmada iş hayatına meslek elemanı yetiştiren ve bu nedenle değişen dünyadan en çok etkilenen meslek yüksekokullarında öğrenim gören öğrencilerin mezuniyet sonrası beklentilerinin değerlendirilmesi esas alınmıştır. Bu kapsamda Ayvacık Meslek Yüksekokulu'nun farklı programlarında öğrenim gören öğrencilerin mezuniyet sonrası mesleki beklenti düzeylerini ölçmek amacıyla Tuncer tarafından geliştirilen 15 soruluk mesleki beklenti ölçeği 202 öğrenciye uygulanmıştır. Analiz sonuçlarına göre Meslek yüksekokulu öğrencilerinin mezuniyet sonrası kariyer beklentileri okudukları sınıfa ve bölüme göre anlamlı farklılık göstermektedir. Buna göre 1. Sınıf da okuyan öğrencilerin 2. sınıf da okuyanlara kıyasla kariyer beklenti düzeylerinin daha yüksek olduğu ve Spor Yönetimi programı öğrencilerinin kariyer beklentilerinin Bankacılık ve Sigortacılık programı öğrencilerine göre daha yüksek olduğu sonuçlarına ulaşılmıştır.

\author{
Anahtar Kelimeler \\ Mezuniyet Sonrası Beklenti \\ Mesleki Beklenti \\ Kariyer \\ Meslek Yüksekokulu \\ Makale Hakkında \\ Geliş Tarihi: 01.02.2021 \\ Kabul Tarihi: 21.06.2021
}

Doi: $10.18026 /$ cbayarsos.872237

\section{Career Expectations of University Students After Graduation: An Example of Ayvacık Vocational School}

Abstract

This study is based on the evaluation of post-graduation expectations of students studying at vocational colleges, which are most affected by the changing world. In this context, the 15-question vocational expectation scale developed by Tuncer in order to measure the post-graduation professional expectation levels of the students studying in different programs of Ayvacik Vocational School was applied to 202 students. Regarding this scale, factor analysis was performed and a two-factor structure was decided. According to the results of the analysis, the career expectations of vocational school students after graduation differ significantly according to their department and the proximity of their graduation. Accordingly, it was found that the career expectation levels of the students studying in the first year were higher compared to the students in the second year and the career expectations of the Sports Management program students were higher than the students of the Banking and Insurance program.
Keywords

Postgraduate Expectation

Professional Expectation

Career

Vocational School

About Article

Received: 01.02.2021

Accepted: 21.06.2021

Doi: 10.18026/cbayarsos.872237

\footnotetext{
a İletişim Yazarı: ykaradeniz@comu.edu.tr

b Dr. Öğr. Üyesi, Çanakkale Onsekiz Mart Üniversitesi, ykaradeniz@comu.edu.tr, ORCID: 0000-0002-5609-5171

c Doç. Dr., Çanakkale Onsekiz Mart Üniversitesi, cigdemozkan@comu.edu.tr , ORCID: 0000-0002-9823-4117
} 


\section{Giriş}

Üniversitelerin önemli bir parçası olan Meslek Yüksekokullarının en önemli misyonu çeşitli sektörlerde ihtiyaç duyulan ara eleman ihtiyacını karşılamaktır. Ancak bu kurumlar bu görevlerini yerini getirmede çeşitli zorluklarla karşılaşmaktadır. Dünyada teknoloji ve kültürel yaşam sürekli değişmekte, piyasa beklentileri değişmekte, çalışanların ihtiyaçları zamanla farklılık göstermektedir. Bundan dolayı da geçmiş beklentilerle bugün ki beklentiler ya da gelecekteki beklentiler birbirinden farklı olmaktadır. Bu durum, tüm eğitim kurumlarını etkilemekte ve kurumların karar verme ve uygulamaya geçme hızlarını yavaşlatmaktadır.

Eğitim kurumlarının en önemli ana parçası olan öğrenciler, öncelikle hem iyi bir üniversiteyi kazanma hem de kazandıkları üniversiteden iyi bir derece ile mezun olmaya çalışmaktadırlar. Bu kapsamda da aynı zamanda kendilerini geleceğe dönük olarak yetiştirmektedirler. Bu süreçte öğrencilerin üniversite yıllarında karar vermek durumunda oldukları çok önemli bir konu da mezuniyet sonrasına ilişkin kariyer planlamalarıdır. (Kılınç ve Ateş, 2014: 434). Diğer bir deyişle meslek tercihi, bireyin yaşamı boyunca verdiği çok önemli kararlardan biridir. Bu bağlamda özellikle son sinıfta mesleki tercih konusu öğrenciler için zaman zaman kaygı ve stres unsuru olabilmektedir.

Kariyer hedeflerini iyi planlamayan ve bunun sonucunda beklentilerini gerçekleştiremeyen gençlerin ümitsizlik ve stres duygularını yaşaması olasıdır. Zamanla bu ümitsizlik ve stres tükenmişliğe de dönüşebilmektedir. Bu yüzen mesleki eğim alan genç çalışanların mesleki tercihlerini en uygun bir biçimde yapmaları ve geleceğe dönük pozitif kariyer beklentilerinin olması çok önemli bir husustur.

İşletmelerde teknoloji sürekli değişmektedir. Değişen teknolojiye işletmelerin ayak uydurması süreklilikleri açısından zorunluluktur. Aynı zamanda işletmelerde çalışacak olan gençlerin sürekli istihdamının sağlanması; ülke ekonomisi açısından, ülkede üretimin artması ve dışa bağımlılığın azalması açısından son derece önemli bir konudur. Bu noktada eğitim sistemiyle ilgili sorunların çözülmesi ve eğitim sisteminin çağdaş bir noktaya ulaşması gençlerin yeni nesil işletmelere uyum süreçlerini kolaylaştıracak ve bireysel anlamda da gelecekle ilgili mesleki motivasyonlarını arttıracaktır. Bu ifade edilen hususlardaki gerçek başarı ise Devlet, Üniversiteler ve İşletmeler arasındaki uyumun bir sonucu olarak ortaya çıkacaktır. Ayrıca, gençlerin kariyer beklentileri bağlamında ailelerinin sosyo-ekonomik düzeylerinin de etkili bir değişken olduğunu literatürdeki birçok araştırma ortaya koymaktadir.

$\mathrm{Bu}$ çalışmada, meslek yüksekokulu öğrencilerinin mezuniyet sonrası kariyer ve duygusal beklentilerinin eşitli değişkenlere göre (bölüm, cinsiyet vb.) değerlendirilmesi ve bu kapsamda anlamlı farklılıklar olup olmadığı araştırılmaktadır. Çalışmaya 2020'li yıllardaki günümüz üniversite öğrencilerinin mevcut kariyer beklentilerini çeşitli değişkenlere göre tespit etmek amacıyla ihtiyaç duyulmuştur. Bu bağlamda çalışmanın güncel olması, mesleki kariyer beklentisi konusunda gelecekte yapılacak daha kapsamlı araştırmalar için yol gösterici olabilir. Günümüz gençlerinin mezuniyet sonrası kariyer beklentileri konusundaki durumlarını tespit etmek ve bu beklentilerini etkileyen değişkenleri ortaya çıkarmak açısından çalışma önem arz etmektedir. 
Özellikle eğitimin öncelikli amaçlarından biri, gençleri gelecekteki iş hayatına hazırlamaktır. Bu bağlamda meslek yüksekokullarına verilen önemin düşük olması da böyle bir bir konuda meslek yüksekokulu öğrencileri üzerinde araştırma yapılması ihtiyacını doğurmuştur.

\section{Kavramsal Çerçeve}

Meslek ve kariyer kavramları, danışma alanında olduğu kadar iş dünyasında, günlük yaşamda pek çok alanda karşımıza çıkan ve birçoğumuzun kullandığı kavramlardır.

Meslek, bir kimsenin hayatını kazanmak için yaptığı, diğer insanlara yararlı bir hizmet ya da ürün sağlamaya yönelik olan, kuralları toplumca belirlenmiş, eğitimle kazanılan bilgi ve becerilere dayalı etkinliklerdir (Kuzgun: 2002; Yeşilyaprak: 2018: 5). Kariyer ise, bir ömür boyu yaşanan olaylar dizisi, bireyin meslek ve diğer yaşam rollerinin birbirini etkilemesi ve izlemesi sonucu meydana gelen genel örüntü ve gelişim çizgisinde, özellikle iş ve mesleğe ilişkin rollerinde ilerleme, duraklama ve gerilemeleri de içeren oldukça geniş bir süreçtir (Yeşilyaprak, 2018: 7).

Günümüzde artık bireylerin kariyerlerini yönetmeleri ve kendilerini geliştirmeleri çok önemli bir konudur. Bu konuyla ilgili olarak da ünlü yönetim düşünürü Peter Drucker bir makalesinde günümüzde herkesin kendisini yönetmeyi öğrenmesi gerektiğini vurgulamaktadır (Dicleli ve Çetinbakış, 2004: 5).

Bireylerin kariyer gelişimlerinde karşılaştıkları birçok sorun vardır. Bu sorunlardan bir bölümü bireyin kendi durumundan kaynaklanmakla birlikte çoğu da firma kültüründen etkilenmektedir. Bireyin kendisinden kaynaklanan sorunların çözümünde kariyer yönetimine önem veren firmalar yardımcı olabilmektedir (Özden, 2008: 308).

Örneğin, bireyin çalışma yaşamının ilk yıllarındaki beklentileri ile gerçeklerin uyuşmaması önemli bir kariyer sorunudur. Bu konuda uyum sürecinde yaşanan sorunların aşılmasında örgütsel sosyalleşme çok önemlidir (Greenhaus, 1987: 122; Erdoğmuş, 2003: 25).

Eğitimin temel amaçlarında biri, bireyleri gelecekteki çalışma yaşamına hazırlamaktır. Ancak bu amacın gerçekleşmesinde günümüzde birçok sıkıntı yaşanmaktadır. Özellikle meslek liselerine ve meslek yüksekokullarına verilen önemin düşük olması bu sıkıntının yaşanmasında önemli bir sebeptir (Özden, 2008: 77).

Zunker (2002), üniversite öğrencilerinin mezun olduktan sonra iş/eğitim konusunda doğru karar verip, seçimlerinin istedikleri alan doğrultusunda olması için kariyer ile iş ayrımını çok iyi kurmaları gerektiğini ifade eder.

Öğrencilerle yakından ilişkili olan kariyer tercihleri, kariyer ihtiyaçları, kariyer planlama, mesleki beklenti, meslek seçimi, mezuniyet sonrası beklentiler vb. konularda literatürde farklı değişkenlerle açıklanmış birçok çalışma vardır. Aşağıda bunlardan bazılarına kısaca yer verilmiştir.

Tuncer'e göre (2011: 935) ülkemizde kariyer tercihlerine bakıldığında bu tercihlerin bireysel idealler, ekonomik koşullar, rol modeller ve tesadüfi olarak yapıldığı söylenebilir. Çakır' a göre ise (2007: 138) meslek seçiminde mesleki saygınlık ve yüksek gelir olgusu ön plana çıkarılmaktadır. Bu durum genç neslin bir bakıma risk almasıdır. Çünkü iş doyumu yaşam doyumu ile ilişkili bulunmakta, kişinin fizik ve ruh sağlığını doğrudan etkilemektedir (Sevimli ve İşcan, 2005: 55). Mesleki anlamda bireylerin kendilerine uygun pozisyonlara 
yerleştirilmemesi, mutsuz çalışanların ortaya çıkmasına neden olur. Bu durum aynı zamanda üretim kayıplarına yol açabilir.

İş yaşamına geçiş sürecinin daha sağlıklı geçirilmesinde öncelikli olan bir özellik olarak kariyer kararı verme yetkinliği karşımıza çıkmaktadır ve bu basamakta yapılacak olan çalışmaların bireylerin kendilerine uygun seçeneklere yönelmelerinde etkili olacağ1 görülmektedir. Literatür incelendiğinde de öğrencilerin kariyer kararı verme yetkinliği düzeylerinin çeşitli değişkenler ile ilişkisinin ortaya koyulduğu birçok çalışma vardır (Kılıç, 2018: 251).

Geçmişten günümüze kariyer ihtiyaçları konusunda fark yaratabilecek değişkenlerle ilgili yapılmış çeşitli araştırmalar bulunmaktadır. Bazı araştırma sonuçlarına göre (Atik ve Yalçın: 2010; Chircu: 2013; Karataş ve Gizir: 2013; Nowakowski: 2002)Üniversite öğrencilerinin kariyer gelişim ihtiyaçları sınıf düzeyine göre değişim gösterirken, değişim olmadığını gösteren araştırma sonuçları da (Yerin Güneri ve ark: 2016) vardır. Owen ise çalışmasında (2018: 37), katılımcların cinsiyetlerine, fakültelerine, sınıflarına ve çalışma deneyimlerinin olup olmamasına göre kariyer gelişim ihtiyaçlarının değişmediği sonucuna ulaşmıştır. Bir diğer araştırmada, kadın üniversite öğrencilerinin ilk sırada bulunan kariyer gelişim ihtiyaçları, ilgileriyle eşleşen işler konusunda bilgi almak iken erkek öğrencilerin ilk sırada yer alan ihtiyaçları iyi bir maaş ve avantajlar konusunda müzakere edebilme becerisine sahip olmak şeklinde açıklanmıştır (Nowakowski, 2002).

Diğer bir çalışmada(İçerli ve Arsu: 2019) öğrencilerin kariyer tercihlerini belirlemede etkili olan kariyer değerleri üzerinde kişilik özelliklerinin etkisini incelenmiştir.

Öztemel (2012: 459) ise çalışmasında kariyer karar verme öz yetkinlik ve kontrol odağının lise öğrencilerinin kariyer karasızlıklarını yordayıp yordamadığını incelemiş ve kariyer kararsızlıklarının cinsiyet, okul türü, karar durumu ve SED'e göre karşılaştırmıştır.

Fidan vd. (2018), meslek yüksekokulu öğrenci ve mezunlarının işe geçiş sürecinin betimlenmesini amaç edinen bir çalışma yapmışlardır.

Baldıran ve Şimsek(2018) çalışmasında mesleki eğitim alan kadınların başarı düzeyleri ile işgücüne katılımları arasında bir ilginin olup olmadığını araştırmıştır ve kadınların mesleki eğitimdeki başarıları ile istihdama katılımları arasında bir ilişkinin olmadığı sonucuna varmışlardır.

Gerçek (2018) ise çalışmasında öğretmen adaylarının öğretmenlik mesleğine ilişkin kaygılarının artması, gelecekte iş bulmalarında ve kariyerlerinde ilerlemelerine ilişkin karşılaşabilecekleri sorunların üstesinden gelebilme ve beklenmedik değişimlere uyum sağlayabilme konusundaki inançlarını azaltmaktadır sonucuna varmıştır.

Farklı bir çalışmada ise Süer vd. (2017), para tutumunun, kariyer hedefleri üzerindeki etkisini incelemişlerdir ve analizler sonucunda, erkeklere göre kadınların parayı bir güçve prestij sembolü olarak görme eğilimlerinin daha düşük olduğu, daha tutumlu ve finansal planlamaya daha eğilimli oldukları tespit edilmiştir.

Ilgar ve Cihan (2019) yaptıkları çalışmada ise, katılımcılar görüşleri doğrultusunda, politika olarak eğitim planlamasında yanlışlıklar olduğu ve spor yönetimi alanında istihdam düzenlemesinin yapılması gerekliliği üzerinde durmuşlardır. Ayrıca katılımcıların, psikolojik olarak kendilerini iyi hissetmeme hali, gelecekten çok umutlu olamama, duygusal olarak tükenmişlik, çevre baskısı, şeklinde problemler yaşadığı sonucuna da ulaşılmıştır. 
Dörtyol (2017) ise çalışmasında, Tıp fakültesi son sınıf öğrencilerinin mezuniyet sonrası ile ilgili düşüncelerini, kariyer seçimlerini ve bunları etkileyen faktörleri incelemiştir.

Günay ve Akıncı (2017) ise turizm eğitimi almakta olan öğrencilerin sektöre karşı olan tutumları ve bu tutumlarının mezuniyet sonrası kariyer seçimlerine etkilerinin belirlenmesi amacıyla bir çalışma yapmışlardır ve öğrencilerin mezuniyet sonrasında sektörde kariyer yapma isteklerini etkileyen en önemli faktörlerin "kişi- endüstri uyumu", "iş arkadaşlı̆̆ ile işe bağlılık" ve "yöneticilerin tutumu" olduğunu saptamışlardır.

Serdar vd. (2013) yaptıkları çalışmada, üniversite mezunu ebeveynlere sahip öğrencilerin kariyer beklentilerinin daha düşük olduğu sonucuna ulaşılmıştır. İşsizlik riski, kariyer beklentileri üzerinde etki yaparken; düşük kariyer beklentilerinin işsizlerde olduğu gibi, üniversite öğrencileri arasında da marjinalleşmeyi besleyen bir etkiye sahip olduğu görülmüştür.

Bireylerin başarılı ve başarısız olmalarında çok önemli bir etken meslek seçimidir. Literatürde meslek seçimi konusunda da birçok çalışma yapılmıştır. Bu çalışmalarda hem meslek seçimini etkileyen faktörler hem de meslek seçiminin özellikle kişilik özellikleri ile ilişkileri açıklanmıştır (Köroğlu, 2014: 140). Bu çalışmada gelecek beklentileri ölçeği ile katılımcılara ilişkin çeşitli değişkenler (cinsiyet, gelir seviyesi, yaşanılan yer, anne eğitin durumu, okunulan bölüme ilişkin düşünceleri vb.) arasındaki ilişkiler araştırılmıştır. Bu anlamda alan yazında yapılan diğer çalışmalardan farklılık göstermektedir. Özellikle okunulan bölümü bilinçli tercih edenler ile etmeyenler arasındaki farkların ortaya çıkarılması ve okunulan bölümden memnun olup olmama ile mesleki beklenti arasındaki ilişkiyi belirlemeye çalışmak, bu çalışmanın özgün kısmını oluşturmaktadır.

\section{Yöntem}

\section{Araştırmanın Amacı ve Hipotezler}

$\mathrm{Bu}$ araştırmanın amacı, meslek yüksekokulu öğrencilerinin mezuniyet sonrası kariyer ve duygusal beklentilerinin eşitli değişkenlere göre (bölüm, cinsiyet vb.) değerlendirilmesi ve bu kapsamda anlamlı farklılıklar olup olmadığını araştırmaktır. Araştırmanın amacı çerçevesinde oluşturulan hipotezler aşağıdaki gibidir:

H1: Kariyer beklentisi ile cinsiyet arasında bir ilişki vardır.

H2: Duygusal beklenti ile cinsiyet arasında bir ilişki vardır.

H3: Kariyer beklentisi ile sınıf düzeyleri arasında bir ilişki vardır.

H4: Duygusal beklenti ile sınıf düzeyleri arasında bir ilişki vardır.

H5: Kariyer beklentisi ile yaşanılan yer arasında bir ilişki vardır.

H6: Duygusal beklenti ile yaşanılan yer arasında bir ilişki vardır.

H7: Kariyer beklentisi ile mezun olunan lise arasında bir ilişki vardır.

H8: Duygusal beklenti ile mezun olunan lise arasında bir ilişki vardır.

H9: Kariyer beklentisi ile gelir durumu arasında bir ilişki vardır.

H10: Duygusal beklenti ile gelir durumu arasında bir ilişki vardır. 
H11: Kariyer beklentisi ile kayıtlı olunan bölüm arasında bir ilişki vardır.

H12: Duygusal beklenti ile kayıtlı olunan bölüm arasında bir ilişki vardır.

H13: Kariyer beklentisi ile anne eğitim durumu arasında bir ilişki vardır.

H14: Duygusal beklenti ile anne eğitim durumu arasında bir ilişki vardır.

H15: Kariyer beklentisi ile kayıtlı olunan bölümü isteyerek yazma arasında bir ilişki vardır.

H16: Duygusal beklenti ile kayıtlı olunan bölümü isteyerek yazma arasında bir ilişki vardır.

H17: Kariyer beklentisi ile kayıtlı olunan bölümü mecburen yazma arasında bir ilişki vardır.

H18: Duygusal beklenti ile kayıtlı olunan bölümü mecburen yazma arasında bir ilişki vardır.

H19: Kariyer beklentisi ile kayıtlı olunan bölümden memnun olma arasında bir ilişki vardır.

H20: Duygusal beklenti ile kayıtlı olunan bölümden memnun olma arasında bir ilişki vardır.

\section{Veri Toplama Aracı}

Araştırmada öğrencilere yüz yüze anket uygulaması yapılmıştır. Anket formu iki bölümden oluşmaktadır. Birinci bölümde katılımcılara ait tanımlayıcı bilgilere yönelik sorular yer almaktadır. İkinci bölümde katılımcıların mesleki beklenti düzeylerini ölçmek amacıyla Tuncer (2011) tarafından geliştirilen mesleki beklenti ölçeği kullanılmıştır. Bu çalışmada, "gelecek beklentileri ölçeği" MYO öğrencilerinin kariyer beklentileri özelinde kullanılmıştır. 15 maddeden oluşan toplam 250 anket basılarak öğrencilere dağıtılmıştır. 3-20 Mart 2019 tarihleri arasında yapılan araştırmaya toplam 220 kişi katılmıştır. Araştırmadan elde edilen veriler SPSS 22 paket programına aktarılarak analiz edilmiştir. Toplanan anketlerin 18 tanesinde eksik veri tespit edildiğinden analize toplam 202 anket dahil edilmiştir. Ölçekle ilgili olarak faktör analizi yapılarak iki faktörlü yapıda karar kılınmıştır. Faktör 1'e ilişkin Cronbach's Alpha değeri ,839 ; Faktör 2'ye ilişkin Cronbach's Alpha değeri ,741'dir. Ölçek uygulamasıyla elde edilen verilerin analizinde Bağımsız gruplar $\mathrm{t}$ testi, Anova testi, Mann Whitney $U$ testi, Kruskal Wallis $H$ ve Tukey HSD testinden yararlanılmıştır. Meslek Yüksekokulu öğrencilerinin mezuniyet sonrası mesleki beklenti düzeyleri ile kategorik değişkenler arasındaki ilişki analiz sonucu elde edilen bulgularla açılanmaya çalışılmıştır.

\section{Evren ve Örneklem}

Araştırmanın evrenini Çanakkale Onsekiz Mart Üniversitesi Ayvacık Meslek Yüksekokulu öğrencileri oluşturmaktadır. Araştırmada ulaşılabilirlik sebeplerinden dolayı evrenin tamamına ulaşmak yerine örneklem alınma yoluna gidilmiştir. Evren içerisinden örneklemi belirlemek için "olasılığa dayalı olmayan" örnekleme yöntemlerinden "kolayda örnekleme" yöntemi kullanılmıştır. "Kolayda örnekleme yönteminde esas, ankete cevap veren herkesin ankete dâhil edilmesidir. Denek bulma işlevi arzu edilen örneklem büyüklüğüne ulaşılıncaya kadar devam eder" (Altunışık vd. 2012: 142). Araştırmanın örneklemi ise bu yüksekokulda öğrenim görmekte olan 220 öğrenciden oluşmaktadır. Örneklemi oluşturan 220 kişinin \%58'i Bankacılık ve Sigortacılık, \%17'sı Spor Yönetimi, \%15'i Turist Rehberliği, \%5 Turizm ve Otel İşletmeciliği, \%5'i ise İşletme Yönetimi programlarında öğrenim görmektedir. Bu kapsamda araştırmanın sınırlılıkları Ayvacık Meslek Yüksekokulu bünyesinde bulunan programlarda kayıtlı olan öğrencilerdir. Her programda kayıtlı öğrenci sayıları farklılık gösterdiği için bölüm bazında araştırmaya katılan öğrenci sayıları homojen dağılım göstermemektedir. 


\section{Bulgular}

Bu bölümde araştırma kapsamında elde edilen bulgular açıklanmıştır.

\section{Mesleki Beklenti Ölçeği Faktör Analizi Sonucu}

Araştırmada kullanılan mesleki beklenti ölçeği Bartlett's test of sphericity (Bartlettkürelsellik testi)p değeri 0,000 olduğundan değişkenlerin faktör analizi yapmaya uygun olduğu görülmektedir. Benzer şekilde Kaiser-Meyer-Olkin (KMO) örneklem yeterliliği de değişkenler arası korelasyonların faktör analizine uygunluğunu test eder. KMO değeri 0 ile 1 arasında değişir ve KMO'nun 1 alması değişkenlerin birbirleri ile mükemmel bir şekilde hatasız tahmin edileceğini gösterir (Durmuş ve diğ., 2013: 80). Araştırmada kullanılan ölçekte KMO değeri, 857 olduğundan değişkenlerin faktör analizine uygunluğunun mükemmel seviyede olduğu görülmektedir. Araştırmada her bir sorunun tek tek faktör analizine uygunluğunu test etmek için Measures of SamplingAdequacy (MSA) analizi yapılmış ve her bir sorunun MSA değeri 0,50'den büyük çıkmıştır. Bu nedenle ölçekten hiçbir soru çıkarılmamış ve faktör analizi 15 soru üzerinden yapılmıştır.

Faktör analizinde 15 maddenin öz değeri 1 olacak şekilde temel bileşenler analizi öncelikli olmak üzere varimax (25) eksen döndürmesi gerçekleştirilmiştir. Geçerlilik çalışmaları sonucunda ilk olarak ölçeğin 4 faktörlü bir yapıya sahip olduğu bulunmuştur. Ölçekte yer alan soru 2'nin 4. faktörün altında tek başına bir faktör de olduğu görülmüştür. Faktör analizinde her bir faktör en az iki sorudan oluşmalıdır. Bu nedenle bu faktörü oluşturan sorunun analizden çıarılarak faktör analizinin yeniden yapılması gerekmektedir (Durmuş ve diğ., 2013: 85).

Soru 2 çıkartılarak faktör analizini tekrar yaptığımızda, herhangi bir faktör altında tek bir sorunun bulunmaması, birden fazla faktör altında birbirine yakın faktör ağırlığının bulunmaması ve düşük faktör ağırlıklı soruların bulunmaması nedeniyle, ölçekte yer alan sorular 3 faktör altında toplanmıştır. 1. faktörün altında (S9, S8, S7, S10, S1, S11, S3), 2. faktörün altında (S14, S6, S12, S13, S5), 3. faktörün altında (S4, S15) yer almıştır.

Yapılan faktör analizi sonucunda her bir faktör altında yer alan soruların soruluş amaçları ve ifadeleri dikkate alınarak her bir faktöre litaratür ışığında isim verilmeden önce faktörlerin güvenirlik analizleri yapılmalıdır (Durmuş ve diğ., 2013: 89). Her bir faktöre ilişkin güvenirlik sonuçları aşağıdaki gibidir.

Faktör 1'e ilişkin Cronbach's Alpha değeri ,839 olarak bulunmuştur. Her bir soruya ilişkin soru silindiğinde Cronbach's Alpha değeri ,839 un altında bulunmuş olup 1. faktör altında toplanan soruların her birinin gerekli olduğu görülmüştür.

Faktör 2'ye ilişkin Cronbach's Alpha değeri ,741 olarak bulunmuştur. Her bir soruya ilişkin soru silindiğinde Cronbach's Alpha değeri ,741' in altında bulunmuş olup 2. faktör altında toplanan soruların her birinin gerekli olduğu görülmüştür.

Faktör 3'e ilişkin Cronbach's Alpha değeri ,239 olarak bulunmuştur. Soru silindiğinde Cronbach's Alpha değeri hiçbir madde için hesaplanmamıştır. Faktör 3'ü oluşturan sorular bu kavramı anlamlı şekilde açılayamamaktadır. Cronbach's Alpha değerinin düşük olması bu faktörün kullanılmayacağı anlamına gelmektedir (Durmuş ve diğ. 2013: 100). Bu nedenle faktör 3'ü oluşturan sorular bundan sonraki analizlerde kullanılmayacaktır. 
Ayvacık meslek yüksekokulu öğrencilerinin mesleki beklenti düzeylerini ölçmek amacıyla Tuncer tarafından geliştirilen 15 soruluk mesleki beklenti ölçeği 202 öğrenciye uygulanmıştır. Daha sonra anketin geçerliliği ve güvenirliğini sağlamak amacıyla sırasıyla faktör ve güvenirlik analizleri yapılmıştır. Böylece farklı bir örneklem grubuyla yapılan bu çalışmada da literatüre uygun bir sonucun elde edilip edilmediği test edilmiştir. Yapılan faktör analizi sonucunda Soru 2'nin ölçmeyi amaçladığımız kavramları ölçmediği tespit edilmiş ve analiz dışı bırakılmış ve güvenirlik analizine geçilmiştir.

Güvenirlik analizi sonucunda faktör 1 ve faktör 2'nin kullanılabileceği ve faktör 3'ün kullanılamayacağına karar verilmiştir. Kalan sorularla yapılan faktör analizi sonucunda Tablo 1'deki Rotated Component Matrix elde edilmiştir.

Tablo 1. Rotated Component Matrix

\begin{tabular}{|lcc|}
\hline & 1 & Component \\
Soru1 &, 728 & 2 \\
Soru7 &, 714 &, 295 \\
Soru9 &, 700 &, 276 \\
Soru10 &, 700 &, 261 \\
Soru8 &, 694 &,- 028 \\
Soru3 &, 620 &, 292 \\
Soru6 &, 549 &, 479 \\
Soru11 &, 522 &, 462 \\
Soru12 &, 016 &, 750 \\
Soru13 &, 114 &, 734 \\
Soru14 &, 507 &, 579 \\
Soru15 &, 428 &, 503 \\
\hline
\end{tabular}

Tablo 1'de görüleceği gibi, mesleki beklenti ölçeği 2 alt boyuttan oluşmaktadır. Faktörler incelendiğinde daha önce elde edilen Faktör 2 de yer alan soru 6' nin, Faktör 1'in altında yer aldığı görülmektedir. Bu nedenle her bir faktör için Cronbach's Alpha değerleri yeniden hesaplanmıştır.

Yapılan ikinci faktör analizi varyansın \% 52,76'sini açıklamıştır. Maddelerin faktör yükleri hesaplandığında, 12 maddenin faktör yüklerinin 0,553 ile 0,849 arasında değss,tiğ anlaşılmaktadır. KMO ölçek geçerliliği 0, 879 olarak hesaplanmıştır. Bartlett küresellik test değeri 890,780 olup; bu değer 0,001 düzeyinde anlamlıdır. Faktör analizi sonuçları Tablo 2' de sunulmuştur. Buna göre, mesleki beklenti ölçeğinin iki boyutta incelenebileceğini söylemek olanaklıdır. 
Mesleki beklenti ölçeğinde yapılan faktör analizi sonucu elde edilen birinci faktör "Kariyer Beklentisi" olarak adlandırılmıştır. Bu faktör 8 ifadeden oluşmakta ve toplam varyansın\% 32.616'sini açıklamaktadır. Çalışmada elde edilen ikinci faktör "Duygusal Beklenti” olarak adlandırılmıştır. Ve bu faktör 4 ifadeden oluşmakta olup toplam varyansın \% 20, 151'ini açıklamaktadır.

Tablo 2. Mesleki Beklenti Faktör Analizi Sonuç Tablosu

Faktörler Güvenirlik

Faktörün Ağırlığı Faktörün Açıklayıcılığı(\%) Kariyer Beklentisi( 8 ifade)

S1 Benimle gurur duyulacak bir meslekte çalışacağım.

S3 Yeteneklerimi göstereceğim , 839 bir işte çalışacağım. S6 Toplumda saygi duyulan , 843 bir meslekte çalışacağım. S7 Kazancı bol olan bir işte çalışacağım S8 Entelektüel kişilerle birlikte çalışacağım.

S9 Yükselebilme imkanı olan bir işte çalışacağım. S10 Yapacağım işten zevk alacağım S11 Yapacağım iş bana lüks bir hayat sunacak.

Duygusal Beklenti (4 ifade)

S5 Beni sıkmayan bir işte çalışacağım. S12 Yapacağım iş cinsiyetime uygun olacak. S13 Yapacağım iş özel yaşamıma engel olmayacak. S14 Seçeceğim meslek geleceğimi güven altına alacak.

$\begin{aligned} & , 839 \\ & , 843 \\ 32,616 & , 839 \\ & , 856 \\ & , 839 \\ & , 833 \\ & , 843\end{aligned}$
güven altına alacak.

Toplam 52,767

$\begin{array}{ll} & , 673 \\ 20,151 & , 673 \\ & , 593\end{array}$

,605

(n)


Tablo 3. Katılımclların Kategorik Özelliklerine İlişkin Frekans ve Yüzde Analizleri Sonucu

\begin{tabular}{|c|c|c|}
\hline Cinsiyet & $\mathrm{f}$ & $\%$ \\
\hline Erkek & 93 & 46 \\
\hline Kadın & 109 & 54 \\
\hline Sinıfi & $\mathrm{f}$ & $\%$ \\
\hline 1.Sinif & 149 & 73,8 \\
\hline 2. Sinif & 53 & 26,2 \\
\hline Ailenin Yaşadığı Yer & $\mathrm{f}$ & $\%$ \\
\hline Köy & 27 & 13,4 \\
\hline İlçe & 91 & 45,0 \\
\hline İl & 84 & 41,6 \\
\hline Mezun Olunan Lise & $\mathrm{f}$ & $\%$ \\
\hline Düz Lise & 15 & 7,4 \\
\hline Anadolu Lisesi & 85 & 42,1 \\
\hline Meslek Lisesi & 92 & 45,5 \\
\hline Diğer & 10 & 5 \\
\hline Ailenin Gelir Durumu & $\mathrm{f}$ & $\%$ \\
\hline $0-1000 \mathrm{TL}$ & 12 & 5,9 \\
\hline 1001- $2000 \mathrm{TL}$ & 45 & 22,3 \\
\hline 2001-3000 TL & 81 & 40,1 \\
\hline 3001-4000 TL & 36 & 17,8 \\
\hline 4001-5000 TL & 19 & 9,4 \\
\hline 6000 ve üzeri & 9 & 4,5 \\
\hline \multicolumn{3}{|l|}{ Bölüm } \\
\hline Turizm ve Otel İşletmeciliği & 10 & 5,0 \\
\hline Turist Rehberliği & 31 & 15,3 \\
\hline Bankacılık ve Sigortacılık & 117 & 57,9 \\
\hline İşletme Yönetimi & 10 & 5 \\
\hline Spor Yönetimi & 34 & 16,8 \\
\hline \multicolumn{3}{|l|}{ Anne Eğitim Düzeyi } \\
\hline Okuma yazma bilmiyor & 7 & 3,5 \\
\hline İlköğretim & 99 & 49,0 \\
\hline Orta Öğretim & 61 & 30,2 \\
\hline Lise & 31 & 15,3 \\
\hline Üniversite & 4 & 2,0 \\
\hline \multicolumn{3}{|l|}{ Baba Eğitim Düzeyi } \\
\hline Okuma yazma bilmiyor & 2 & 1,0 \\
\hline İlköğretim & 93 & 46,0 \\
\hline Orta Öğretim & 46 & 22,8 \\
\hline Lise & 46 & 22,8 \\
\hline Üniversite & 14 & 6,9 \\
\hline Lisans Üstü & 1 &, 5 \\
\hline Okuduğum Bölümü İsteyerek Yazdım & f & $\%$ \\
\hline Evet & 128 & 63,4 \\
\hline Hayır & 74 & 36,6 \\
\hline Okuduğum Bölümü Mecburen Yazdım & $\mathrm{f}$ & $\%$ \\
\hline Evet & 73 & 36,1 \\
\hline Hayır & 129 & 63,9 \\
\hline Okuduğum Bölümden Memnunum & f & $\%$ \\
\hline Evet & 149 & 73,8 \\
\hline Hayır & 53 & 26,2 \\
\hline
\end{tabular}

Tablo 4. Kariyer ve Duygusal Beklenti Boyutlarının Cinsiyete Göre Karşılaştırılmasına İlişkin T-testi Sonuçları

$\begin{array}{llllll}\text { Cinsiyet } & \mathrm{n} & \overline{\mathrm{X}} & \text { s.s. } & \mathrm{t} & \mathrm{p}\end{array}$




\begin{tabular}{|c|c|c|c|c|c|c|}
\hline \multicolumn{7}{|l|}{ Boyutlar } \\
\hline & Kadın & 109 & 3,77 & ,76 & & \\
\hline \multirow[t]{3}{*}{ Kariyer Beklentisi } & & & & & $-1,797$ & 0,074 \\
\hline & Erkek & 93 & 3,95 & 68 & & \\
\hline & Kadın & 100 & 3,89 & ,75 & & \\
\hline \multirow[t]{2}{*}{ Duygusal Beklenti } & & & & & $-1,015$ & 0,312 \\
\hline & Erkek & 93 & 3,99 & ,71 & & \\
\hline
\end{tabular}

Tablo 4 incelendiğinde kariyer beklentisi $(p=0,074>0,05)$ ve duygusal beklenti $(p=0,312>0,05)$ cinsiyete göre anlamlı farklılık göstermemektedir. Dolayısı ile H1 ve H2 hipotezi red edilmiştir.

Tablo 5. Kariyer ve Duygusal Beklenti Boyutlarının Okudukları Sınıf Düzeylerine Göre Karşılaştırılmasına İlişkin T-testi Sonuçları

\begin{tabular}{|lcccccc|}
\hline Boyutlar & Sinıfi & $\mathbf{n}$ & $\bar{X}$ & s.s. & $\mathbf{t}$ & $\mathbf{p}$ \\
& & & & & & \\
Kariyer Beklentisi & 1.Sinif & 149 & 3,92 &, 70 & & \\
& 2.Sinif & 53 & 3,66 &, 75 & & \\
Duygusal Beklenti & 1.Sinif & 100 & 3,89 &, 75 & & \\
& & & & & 1,886 & 0,061 \\
\hline
\end{tabular}

Tablo 5 incelendiğinde kariyer beklentisi $(p=0,02<0,05)$ olduğundan katılımcılın okuduğu sınıfa göre anlamlı farklılık göstermektedir. Buna göre 1. sınıf da okuyan öğrencilerin 2. sinıf da okuyanlara kıyasla kariyer beklenti düzeylerinin daha yüksek olduğu sonucuna ulaşılmıştır. Dolayısıyla H3 hipotezi kabul edilmiştir.

Duygusal beklenti düzeyi ile katılımcının okuduğu sınıf arasında anlamlı farklılık bulunmamıştır ( $p=0,061>0,05)$. Dolayısıyla H4 hipotezi red edilmiştir.

Araştırmada ANOVA yapılabilmesi için grupların varyansının eşitliği test edilmesi gerekmektedir. Burada ANOVA yapılabilmesi için grup varyanslarının homojen yani eşit olması şartı aranır. Homojenlik testi bir Levene testi ile yapılır (Durmuş ve diğ., 2013, p. 118). ANOVA yapılabilmesi için öncelikleLevene testinde $p$ değerinin $0,05^{\prime}$ den büyük olması 
gerekmektedir. Katılımciların kariyer beklentisi $(\mathrm{p}=0,074>0,05)$ ve duygusal beklenti boyutlarının ailenin yaşadığı yere göre karşılaştırılmasına ilişkin homojenlik testi sonuçları aşağıdaki tabloda gösterilmektedir.

Tablo 6. Katılımcıların Kariyer Beklentisi ve Duygusal Beklenti Boyutlarının Ailenin Yaşadığı Yere İlişkin Homojenlik Testi Sonucu

\begin{tabular}{|lllll|}
\hline Boyutlar & Levene İstatistiği & f1 & df2 & Sig. \\
Kariyer Beklentisi &, 311 & 2 & 199 &, 733 \\
Duygusal Beklenti &, 542 & 2 & 199 &, 582 \\
\hline
\end{tabular}

Tablo 6'da görüleceği gibi Levene testinin sonucunda grupların varyansının eşitliği kabul edilmiştir. ( $p$ değeri kariyerbeklentisi $=0,733>0,05$; duygusal beklenti $=0,582>0,05$ 'den). $\mathrm{Bu}$ durumda ANOVA yapılabilmesi için ön şart sağlanmıştır. Varyansların homojen olması durumunda dört farklı ikili karşılaştırma testi bulunmaktadır. Bunlardan en sık kullanılan ikili karşılaştırma testleri Scheffe ve Tukey'dir. Scheffe testi grupların örnek sayıları eşit olmadığında tercih edilmektedir (Durmuş ve diğ., 2013, p. 128). Tablo 7'de ise kariyer beklentisi, duygusal beklenti boyutlarının katılımcıların ailesinin yaşadığı yere göre karşılaştırılmasına ilişkin ANOVA sonuçları yer almaktadır.

Tablo 7. Kariyer Beklentisi ve Duygusal Beklenti Boyutlarının Katılımcıların Ailelerinin Yaşadığı Yere İlişkin ANOVA Testi Sonuçları

\begin{tabular}{|c|c|c|c|c|c|c|c|}
\hline Boyutlar & Ailenin Yaşadığı yer & $\mathbf{n}$ & $\bar{X}$ & s.s. & F & $\mathbf{p}$ & $\begin{array}{c}\text { Çoklu Karşılaştırma } \\
\text { (Scheffe) }\end{array}$ \\
\hline \multirow{3}{*}{ Kariyer Beklentisi } & İlçe & 91 & 3,78 & 0,96 & \multirow{3}{*}{,892 } & \multirow{3}{*}{411} & \multirow{3}{*}{-} \\
\hline & Köy & 27 & 3,83 & 0,82 & & & \\
\hline & İl & 84 & 3,93 & 0,41 & & & \\
\hline \multirow{3}{*}{ Duygusal Beklenti } & Köy & 27 & 3,81 & 0,78 & \multirow{3}{*}{ 629 } & \multirow{3}{*}{, 534} & \multirow{3}{*}{-} \\
\hline & İlçe & 91 & 3,92 & 0,84 & & & \\
\hline & İl & 84 & 3,99 & 0,54 & & & \\
\hline
\end{tabular}

Tablo 7'ye göre Kariyer Beklentisi $(p=0,411>0,05)$ ve Duygusal Beklenti $(p=0,534>0,05)$ ailenin yaşadığı yere göre 0,05 anlamlılık düzeyinde herhangi bir farklılık göstermemektedir. Dolayısıyla H5 ve H6 hipotezi red edilmiştir. 
Tablo 8. Katılımciların Kariyer Beklentisi ve Duygusal Beklenti Boyutlarının Katılımcıların Mezun Olunan Lise Durumuna İlişkin Homojenlik Testi Sonucu

\begin{tabular}{|lllll|}
\hline Boyutlar & Levene İstatistiği & f1 & df2 & Sig. \\
Kariyer Beklentisi &, 518 & 3 & 198 &, 671 \\
Duygusal Beklenti & 1,206 & 3 & 198 &, 309 \\
\hline
\end{tabular}

Tablo 8'de görüleceği gibi Levene testinin sonucunda grupların varyansının eşitliği kabul edilmiştir. ( $p$ değeri kariyerbeklentisi $=0,671>0,05$; duygusal beklenti $=0,309>0,05$ 'den). $\mathrm{Bu}$ durumda ANOVA yapılabilmesi için ön şart sağlanmıştır.

Tablo 9. Kariyer ve Duygusal Beklenti Boyutlarının Katılımcların Mezun Olunan Lise Durumuna İlişkin ANOVA Testi Sonuçları

\begin{tabular}{|c|c|c|c|c|c|c|c|}
\hline Boyutlar & Mezun Olunan Lise & $\mathbf{n}$ & $\bar{X}$ & s.s. & $\mathbf{F}$ & $\mathrm{p}$ & $\begin{array}{c}\text { Çoklu Karşılaştırma } \\
\text { (Scheffe) }\end{array}$ \\
\hline \multirow{5}{*}{ Kariyer Beklentisi } & Düz Lise & 15 & 4,21 & 0,91 & & & \\
\hline & Anadolu Lisesi & 85 & 3,73 & 0,74 & & & \\
\hline & & & & & 2,244 & 084 & - \\
\hline & Meslek Lisesi & 92 & 3,89 & 0,68 & & & \\
\hline & Diğer & 10 & 3,97 & 0,52 & & & \\
\hline \multirow{5}{*}{ Duygusal Beklenti } & Düz Lise & 15 & 4,15 & 0,73 & & & \\
\hline & Anadolu Lisesi & 85 & 3,82 & 0,77 & & & \\
\hline & & & & & 1,515 & ,212 & - \\
\hline & Meslek Lisesi & 92 & 3,99 & 0,70 & & & \\
\hline & Diğer & 10 & 4,12 & 0,53 & & & \\
\hline
\end{tabular}

Buna göre Kariyer Beklentisi $(\mathrm{p}=0,084>0,05)$ ve Duygusal Beklenti $(\mathrm{p}=0,212>0,05)$ mezun olunan liseye göre 0,05 anlamlılık düzeyinde herhangi bir farklılık göstermemektedir. Dolayısıyla H7 ve H8 hipotezi red edilmiştir. 
Tablo 10. Katılımcıların Kariyer Beklentisi ve Duygusal Beklenti Boyutlarının Gelir Durumuna Göre Homojenlik Testi Sonucu

\begin{tabular}{|lllll|}
\hline Boyutlar & Levene İstatistiği & f1 & df2 & Sig. \\
Kariyer Beklentisi &, 977 & 5 & 196 &, 433 \\
Duygusal Beklenti &, 436 & 5 & 196 &, 823 \\
\hline
\end{tabular}

Tablo 10'da görüleceği gibi Levene testinin sonucunda grupların varyansının eşitliği kabul edilmiştir. ( $p$ değeri KariyerBeklentisi $=0,433>0,05$; Duygusal Beklenti $=0,823>0,05$ 'den). Bu durumda ANOVA yapılabilmesi için ön şart sağlanmıştır.

Tablo 11. Kariyer ve Duygusal Beklenti Boyutlarının Katılımcıların Gelir Duruma İlişkin ANOVA Testi Sonuçları

\begin{tabular}{|c|c|c|c|c|c|c|c|}
\hline Boyutlar & Gelir Durumu & $\mathbf{n}$ & $\bar{X}$ & s.s. & $\mathbf{F}$ & p & $\begin{array}{c}\text { Çoklu Karşılaştırma } \\
\text { (Scheffe) }\end{array}$ \\
\hline \multirow{6}{*}{ Kariyer Beklentisi } & 0-1000 TL & 12 & 4,05 & 87 & \multirow{6}{*}{,545 } & \multirow{6}{*}{,742 } & \multirow{12}{*}{ - } \\
\hline & $1001-2000 \mathrm{TL}$ & 45 & 3,83 &, 80 & & & \\
\hline & 2001-3000 TL & 81 & 3,91 & 64 & & & \\
\hline & 3001-4000 TL & 36 & 3,80 & 63 & & & \\
\hline & $4001-5000 \mathrm{TL}$ & 19 & 3,68 & ,95 & & & \\
\hline & 5001 ve üzeri & 9 & 3,76 & 70 & & & \\
\hline \multirow{6}{*}{ Duygusal Beklenti } & $0-1000 \mathrm{TL}$ & 12 & 3,79 & 90 & \multirow{6}{*}{,506 } & \multirow{6}{*}{ 772 } & \\
\hline & 1001-2000 TL & 45 & 3,97 & 77 & & & \\
\hline & 2001-3000 TL & 81 & 4,01 & 65 & & & \\
\hline & $3001-4000 \mathrm{TL}$ & 36 & 3,83 & 75 & & & \\
\hline & $4001-5000 \mathrm{TL}$ & 19 & 3,85 & 83 & & & \\
\hline & 5001 ve üzeri & 9 & 3,88 & 73 & & & \\
\hline
\end{tabular}

Buna göre Kariyer Beklentisi $(p=0,742>0,05)$ ve Duygusal Beklenti $(p=0,772>0,05)$ gelir durumuna göre 0,05 anlamlılık düzeyinde herhangi bir farklılık göstermemektedir. Dolayısıyla H9 ve H10 hipotezi red edilmiştir. 
Tablo 12. Katılımcıların Kariyer Beklentisi ve Duygusal Beklenti Boyutlarının Okudukları Bölüme İlişkin Homojenlik Testi Sonucu

\begin{tabular}{|lllll|}
\hline Boyutlar & Levene İstatistiği & f1 & df2 & Sig. \\
Kariyer Beklentisi & 4,23 & 4 & 197 &, 003 \\
Duygusal Beklenti & 1,219 & 4 & 197 &, 304 \\
\hline
\end{tabular}

Tablo 12'de görüleceği gibi Levene testinin sonucunda kariyer beklentisi boyutunda grupların varyansının eşitliği kabul edilmemiştir. Bu durumda ANOVA yapılabilmesi için ön şart sağlanmamıştır ( $p$ değeri kariyerbeklentisi $=0,003<0,05$ ). Grup varyanslarının eşit olmadığı durumlarda Alternatif olarak Welch ve Brow-Forsythe testleri uygulanabilir. İki test arasında da Welch testi daha güçlü olup daha sık kullanılmaktadır (Durmuş ve diğ., 2013: 133).

Duygusal Beklenti $\mathrm{p}$ değeri $=0,304>0,05$ bulunmuştur. Bu durumda grupların varyansının eşitliği kabul edilmiştir. Böylece ANOVA yapılabilmesi için ön şart sağlanmıştır.

Tablo 13. Duygusal Beklenti Boyutunun Katılımcıların Okudukları Bölüme İlişkin ANOVA Testi Sonuçları

\begin{tabular}{|c|c|c|c|c|c|c|c|}
\hline \multirow[t]{4}{*}{ Boyutlar } & Bölüm & $\mathbf{n}$ & $\bar{X}$ & s.s. & $\mathbf{F}$ & $\mathrm{p}$ & $\begin{array}{c}\text { Çoklu Karşılaştırma } \\
\text { (Scheffe) }\end{array}$ \\
\hline & Turizm ve Otel İşl. & 10 & 4,10 & ,48 & & & \\
\hline & Turist Rehberliği & 31 & 3,88 & 90 & & & \\
\hline & Bankacılık ve Sigortacilık & 117 & 3,87 & ,70 & & & \\
\hline \multirow[t]{4}{*}{ Duygusal Beklenti } & & & & & 2,941 & 022 & Spor yönetimi-Bankacıllk \\
\hline & İşletme Yönetimi & 10 & 3,57 & 81 & & & \\
\hline & El Sanatları & 1 & 3,25 & - & & & \\
\hline & Spor Yönetimi & 33 & 4,31 &, 58 & & & \\
\hline
\end{tabular}

Scheffe sonuçlarına göre spor yönetimi öğrencilerinin duygusal beklenti düzeylerinin bankacilık öğrencilerine göre daha yüksek olduğu sonucuna ulaşılmıştır. Dolayısıyla H12 hipotezi kabul edilmiştir. 
Tablo 14. Kariyer Beklentisi boyutunun Katılımcıların Okudukları Bölüme İlişkin Welch Sonuçları

\begin{tabular}{|llllllll|}
\hline & & Statistic & df1 & df2 & p & Tamhane's T2 \\
Kariyer Beklentisi & Welch & 6,59 & 4 & 34,210 & 0,000 & Spor Yönetimi-Bankacillk \\
\hline
\end{tabular}

Tablo 14' de katılımcıların kariyer beklentilerinin okudukları bölüme göre karşılaştırılmasına ilişkin Welch sonuçları yer almaktadır. Buna göre katılımcıların kariyer beklentileri $(p=0,000<$ 0,05) okudukları bölüme göre anlamlı farklılık göstermektedir.

Farklılıkların hangi ikili gruptan kaynaklandığını gösteren çoklu karşılaştırma testi Tamhane's sonuçları aşağıdaki tabloda gösterilmektedir.

Tablo 15. Kariyer Beklenti Boyutunun Katılımcıların Okudukları Bölüme İlişkin Tamhane’s Testi Sonuçları

\begin{tabular}{|c|c|c|c|c|}
\hline $\begin{array}{l}\text { Katılımcının Okudukları Bölüm } \\
\text { (I) }\end{array}$ & $\begin{array}{c}\text { Katılımcının Okudukları bölüm } \\
(\mathrm{J})\end{array}$ & $\begin{array}{l}\text { Ortalama Farkları } \\
\qquad(\mathrm{I}-\mathrm{J})\end{array}$ & $\begin{array}{c}\text { Standart } \\
\text { Sapma }\end{array}$ & Sig. \\
\hline \multirow{4}{*}{ Turizm ve Otel İşl. } & Turist Rehberliği & 00121 & 17870 & 1,000 \\
\hline & Bankacilık & 33024 & 13221 & ,216 \\
\hline & İşletme Yönetimi & ,50000 & ,38689 & ,920 \\
\hline & Spor Yönetimi &,- 20147 & 14207 & ,848 \\
\hline \multirow{4}{*}{ Turist Rehberliği } & Turizm ve Otel İşl. &,- 00121 & 17870 & 1,000 \\
\hline & Bankacilık & ,32903 & 15162 & ,302 \\
\hline & İşletme Yönetimi & 49879 & ,39395 & ,927 \\
\hline & Spor Yönetimi &,- 20268 & 16030 & ,908 \\
\hline \multirow{4}{*}{ Bankacılık } & Turizm ve Otel İşl. &,- 33024 & 13221 & ,216 \\
\hline & Turist Rehberliği &,- 32903 & 15162 & ,302 \\
\hline & İşletme Yönetimi & 16976 & ,37516 & 1,000 \\
\hline & Spor Yönetimi &,$- 53171^{*}$ & 10602 & ,000 \\
\hline \multirow{4}{*}{ İşletme Yönetimi } & Turizm ve Otel İşl. &,- 50000 & ,38689 & ,920 \\
\hline & Turist Rehberliği &,- 49879 & ,39395 & ,927 \\
\hline & Bankacilık &,- 16976 & ,37516 & 1,000 \\
\hline & Spor Yönetimi &,- 70147 & ,37875 & ,627 \\
\hline \multirow{4}{*}{ Spor Yönetimi } & Turizm ve Otel İşl. & 20147 & 14207 &, 848 \\
\hline & Turist Rehberliği & 20268 & 16030 & ,908 \\
\hline & Bankacilık &, $53171^{*}$ & 10602 & ,000 \\
\hline & İşletme Yönetimi & 70147 & ,37875 & ,627 \\
\hline
\end{tabular}

Farklılıkların hangi ikili gruptan kaynaklandığını gösteren çoklu karşılaştırma testi (Tamhane's) sonuçlarına göre Spor Yönetimi öğrencilerinin kariyer beklentiler Bankacılık ve Sigortacılık öğrencilerine göre daha yüksektir. Dolayısıyla H11 hipotezi kabul edilmiştir. 
Tablo 16. Duygusal ve Kariyer Beklenti Boyutlarının Katılımcıların Anne Eğitim Durumuna İlişkin Homejenlik Testi Sonuçları

\begin{tabular}{|lllll|}
\hline Boyutlar & Levene İstatistiği & f1 & df2 & Sig. \\
Kariyer Beklentisi &, 526 & 4 & 197 &, 716 \\
Duygusal Beklenti & 1,794 & 4 & 197 &, 132 \\
\hline
\end{tabular}

Tablo 16'da görüleceği gibi Levene testinin sonucunda grupların varyansının eşitliği kabul edilmiştir. ( $p$ değeri KariyerBeklentisi=0,716>0,05; Duygusal Beklenti= 0,132>0,05'den). Bu durumda ANOVA yapılabilmesi için ön şart sağlanmıştır.

Tablo 17. Kariyer ve Duygusal Beklenti Boyutlarının Katılımcıların Anne Eğitim Duruma İlişkin ANOVA Testi Sonuçları

\begin{tabular}{|c|c|c|c|c|c|c|c|}
\hline Boyutlar & Anne Eğitim Durumu & $\mathbf{n}$ & $\bar{X}$ & s.s. & $\mathbf{F}$ & $\mathbf{p}$ & $\begin{array}{c}\text { Çoklu Karşılaştırma } \\
\text { (Scheffe) }\end{array}$ \\
\hline \multirow[t]{5}{*}{ Kariyer Beklentisi } & Okuma Bilmiyor & 7 & 3,8929 & 74801 & & & \\
\hline & İlk Öğretim & 99 & 3,8990 & 75839 & & & \\
\hline & Orta Öğretim & 61 & 3,8975 & 64449 &, 569 & 685 & - \\
\hline & Lise & 31 & 4,1452 & ,72679 & & & \\
\hline & Üniversite & 4 & 4,1250 & 1,42156 & & & \\
\hline \multirow[t]{5}{*}{ Duygusal Beklenti } & Okuma Bilmiyor & 7 & 4,0893 &, 57606 & & & \\
\hline & İlk Öğretim & 99 & 3,8447 & ,73455 & & & \\
\hline & Orta Öğretim & 61 & 3,7807 & ,75092 & 801 &, 526 & - \\
\hline & Lise & 31 & 3,9556 & ,72855 & & & \\
\hline & Üniversite & 4 & 4,0625 & ,48412 & & & \\
\hline
\end{tabular}

Buna göre Kariyer Beklentisi $(p=0,685>0,05)$ ve Duygusal Beklenti $(p=0,801>0,05)$ gelir durumuna göre 0,05 anlamlılık düzeyinde herhangi bir farklılık göstermemektedir. Dolayısıyla H13 ve H14 hipotezi red edilmiştir. 
Tablo 18. Kariyer ve Duygusal Beklenti Boyutlarının Katılımcıların Okudukları Bölümü İsteyerek Yazıp Yazmama Durumuna Göre Karşılaştırılmasına İlişkin T-testi Sonuçları

\begin{tabular}{|c|c|c|c|c|c|c|}
\hline \multicolumn{6}{|l|}{ Boyutlar } & $\mathrm{p}$ \\
\hline & Evet & 128 & 4,01 & 62 & & \\
\hline \multirow[t]{3}{*}{ Kariyer Beklentisi } & & & & & 4,265 & 0,000 \\
\hline & Hayır & 74 & 3,57 & 80 & & \\
\hline & Evet & 128 & 4,03 & 67 & & \\
\hline \multirow[t]{2}{*}{ Duygusal Beklenti } & & & & & 2,386 & 0,018 \\
\hline & Hayır & 74 & 3,78 & 79 & & \\
\hline
\end{tabular}

Tablo 18 incelendiğinde kariyer beklentisi $(p=0,000<0,05)$ ve duygusal beklenti $(\mathrm{p}=0,018<0,05)$ okudukları bölümü isteyerek yazıp yazmama durumuna göre anlamlı farklılık göstermektedir. Buna göre okudukları bölümü isteyerek yazanların yazmayanlara kıyasla duygusal ve kariyer beklenti düzeyleri daha yüksektir. Dolayısıyla H15 ve H16 hipotezleri kabul edilmiştir.

Tablo 19. Kariyer ve Duygusal Beklenti Boyutlarının Katılımcıların Okudukları Bölümü Mecburen Yazıp Yazmama Durumuna Göre Karşılaştırılmasına İlişkin T-testi Sonuçları

\begin{tabular}{|c|c|c|c|c|c|c|}
\hline \multirow[t]{2}{*}{ Boyutlar } & Okuduğum Bölümü Mecburen Yazdım & $\mathbf{n}$ & $\overline{\mathrm{X}}$ & s.s. & $\mathbf{t}$ & $\mathrm{p}$ \\
\hline & Evet & 73 & 3,57 & ,78 & & \\
\hline \multirow[t]{3}{*}{ Kariyer Beklentisi } & & & & & $-4,255$ & 0,000 \\
\hline & Hayır & 129 & 4,01 & 64 & & \\
\hline & Evet & 73 & 3,78 & ,75 & & \\
\hline \multirow[t]{2}{*}{ Duygusal Beklenti } & & & & & $-2,250$ & 0,026 \\
\hline & Hayır & 129 & 4,02 & ,71 & & \\
\hline
\end{tabular}

Tablo 19 incelendiğinde kariyer beklentisi $(\mathrm{p}=0,000<0,05)$ ve duygusal beklenti $(\mathrm{p}=0,026<0,05)$ okudukları bölümü mecburen yazıp yazmama durumuna göre anlamlı farklılık göstermektedir. Buna göre okudukları bölümü mecburen yazanların yazmayanlara 
kıyasla duygusal ve kariyer beklenti düzeyleri daha düşüktür. Dolayısıla H17 ve H18 hipotezi kabul edilmiştir.

Tablo 20. Kariyer ve Duygusal Beklenti Boyutlarının Katılımcıların Okudukları Bölümden Memnun Olup Olmama Durumuna Göre Karşılaştırılmasına İlişkin T-testi Sonuçları

\begin{tabular}{|lccccccc|}
\hline & Okuduğum Bölümden Memnunum & $\mathbf{n}$ & $\bar{X}$ & s.s. & $\mathbf{t}$ & $\mathbf{p}$ \\
Boyutlar & Evet & & & & & \\
Kariyer Beklentisi & Hayır & 149 & 3,99 &, 61 & & \\
& & & & & 4,243 & 0,000 \\
& Evet & 53 & 3,45 &, 86 & & \\
Duygusal Beklenti & Hayır & 149 & 4,02 &, 67 & & \\
& & & & & $-2,907$ & 0,004 \\
& & 53 & 3,69 &, 83 & & \\
\hline
\end{tabular}

Tablo 20 incelendiğinde kariyer beklentisi $(p=0,000<0,05)$ ve duygusal beklenti $(\mathrm{p}=0,004<0,05)$ okudukları bölümden memnun olup olmama durumuna göre anlamlı farklılık göstermektedir. Buna göre okudukları bölümden memnun olanların olmayanlara kıyasla duygusal ve kariyer beklenti düzeyleri daha yüksektir. Dolayısıyla H19 ve H20 hipotezleri kabul edilmiştir.

Aşağıda Tablo 21'de araştırma hipotezlerine ilişkin Kabul/Red durumları toplu olarak gösterilmiştir.

Tablo 21. Araştırma Hipotezlerinin Kabul / Red Olma Durumu 


\section{HIPOTEZLER}

H1: Kariyer beklentisi ile cinsiyet arasında bir ilişki vardır.

RED

H2: Duygusal beklenti ile cinsiyet arasında bir ilişki vardır.

RED

H3: Kariyer beklentisi ile sınıf düzeyleri arasında bir ilişki vardır.

KABUL

H4: Duygusal beklenti ile sınıf düzeyleri arasında bir ilişki vardır.

RED

H5: Kariyer beklentisi ile yaşanılan yer arasında bir ilişki vardır.

RED

H6: Duygusal beklenti ile yaşanılan yer arasında bir ilişki vardır.

RED

H7: Kariyer beklentisi ile mezun olunan lise arasında bir ilişki vardır.

RED

H8: Duygusal beklenti ile mezun olunan lise arasında bir ilişki vardır.

RED

H9: Kariyer beklentisi ile gelir durumu arasında bir ilişki vardır.

RED

H10: Duygusal beklenti ile gelir durumu arasında bir ilişki vardır.

RED

H11: Kariyer beklentisi ile kayıtlı olunan bölüm arasında bir ilişki vardır.

KABUL

H12: Duygusal beklenti ile kayıtlı olunan bölüm arasında bir ilişki vardır.

KABUL

H13: Kariyer beklentisi ile anne eğitim durumu arasında bir ilişki vardır.

RED

H14: Duygusal beklenti ile anne eğitim durumu arasında bir ilişki vardır.

RED

H15: Kariyer beklentisi ile kayıtlı olunan bölümü isteyerek yazma arasında bir ilişki vardır.

KABUL

H16: Duygusal beklenti ile kayıtlı olunan bölümü isteyerek yazma arasında bir ilişki vardır.

KABUL

H17: Kariyer beklentisi ile kayıtlı olunan bölümü mecburen yazma arasında bir ilişki vardır.

KABUL

H18: Duygusal beklenti ile kayıtlı olunan bölümü mecburen yazma arasında bir ilişki vardır.

KABUL

H19: Kariyer beklentisi ile kayıtlı olunan bölümden memnun olma arasında bir ilişki vardır.

KABUL

H20: Duygusal beklenti ile kayıtlı olunan bölümden memnun olma arasında bir ilişki vardır.

KABUL

\section{Sonuç ve Öneriler}

Aktaş ve Şahin (2019) lisans öğrencileri üzerinde yaptıkları çalışmada, Kariyer kararsızlığı ile öğrenim görülen bölüme isteyerek gelip gelmeme durumu arasındaki ilişki incelemiş, anlamlı bir farklılığın olduğu $(p=.04>.05)$ ve öğrenim gördükleri bölüme istemeyerek gelenlerin kariyer kararsızlığı ortalama puanlarının isteyerek gelen öğrencilerine göre daha yüksek olduğu sonucuna ulaşmıştır. Meslek yüksekokulu öğrencileri üzerinde yapılan bizim çalışmamızdan elde edilen bulgular, lisans öğrencileri üzerinde yapılan diğer çalışmadaki bulgularla benzerlik göstermektedir.

Kaval ve Gökoğlan (2020) farklı alanlarda eğitim veren fakülteler üzerinde öğrencilerin kariyer eğilimlerini incelemiş ve birçok öğrencinin kariyer geleceği açısından kararsızlık 
yaşadığ1 sonucuna ulaşmıştır. Bizim çalışmamızda da elde edilen bulgularda farklı bölümlerde okuyan öğrencilerde farklı kariyer beklenti düzeyleri ortaya çıkmıştır.

Küçükooğlu vd. (2020) ise, meslek yüksekokulu öğrencilerinin kariyer ve girişimcilik yönelimlerini araştırdıkları çalışmada kariyer yönelimi tercihlerinde bölümler arasında farklılıklar olduğu durumunu gözlemlemişlerdir. Bizim çalışmamızda da farklı bölümlerde okuyan meslek yüksekokulu öğrencilerinin kariyer beklentilerinde farklılıklar çıkmıştır.

Literatürde, öğrencilerin kariyer beklentileri ile ilgili kuramsal çerçevede de bazılarını açıkladığımız farklı açılardan ele alınmış çalışmalar vardır. Bu çalışmayı literatürdeki benzer çalışmalardan farklılaştıran önemli nokta, mezuniyet sonrası kariyer beklentileri ile ilgili olarak, özellikle 2020'li yıllardaki farklı bölümlerde okuyan meslek yüksekokulu öğrencilerinin bakış açılarındaki ve beklentilerindeki mevcut durumu, farklılıkları ortaya koyan güncelliğe sahip olması, aynı zamanda birçok farklı değişkene göre analizlerin yapılmasidır.

Gençlerin mezuniyet sonrası kariyer beklentileri konusundaki durumlarını tespit etmek ve bu beklentilerini etkileyen değişkenleri ortaya çıkarmak amacıyla yapılan araştırmanın sonuçlarına göre;

a) Katılımcıların \% 54'ü (109) kişi kadınlardan, \% 73.8'i (149) kişi 1. Sınıf öğrencilerinden, \% 40.1'i (81) kişi 2000-3000 gelir aralığında olanlardan, \% 57.9'u (117) kişi Bankacılık ve Sigortacılık bölümünde okuyanlardan ve \% 45'i (91) kişi ilçeden gelen kişilerden oluşmaktadır. Araştırmaya katılanlar arasında, okudukları bölümü isteyerek yazanların oranı \% 63.4 (128 kişi), okudukları bölümü mecburen yazanların oranı \% 36.1 (73 kişi), okudukları bölümden memnuniyet düzeyleri ise \% 73.8 (149 kişi) bulunmuştur.

b) 1.sınıfta okuyan öğrencilerin 2. sınıfta okuyanlara kıyasla kariyer beklenti düzeyleri daha yüksek bulunmuştur.

c) Spor yönetimi öğrencilerinin duygusal beklenti düzeyleri, bankacılık öğrencilerine göre daha yüksektir.

d) Spor yönetimi öğrencilerinin kariyer beklenti düzeyleri bankacılık ve sigortacılık öğrencilerine göre daha yüksektir.

e) Okudukları bölümü isteyerek yazan öğrencilerin yazmayanlara kıyasla duygusal ve kariyer beklenti düzeyleri daha yüksektir.

f) Okudukları bölümü mecburen yazanların yazmayanlara kıyasla kariyer ve duygusal beklenti düzeyleri daha düşüktür.

g) Okudukları bölümden memnun olanlar olamayanlara kıyasla kariyer ve duygusal beklenti düzeyleri daha yüksektir.

Çalışma yukarıda elde ettiğimiz bulgular ve sonuçlar kapsamında değerlendirildiğinde, çalışmanın eğitim ve kariyer konularında meslek yüksek okullarına verilen önemin artmasına katkı sağlayabileceği düşünülmektedir. Bu bağlamda, kariyer konularında özellikle meslek yüksekokullarındaki gençlerinin daha fazla bilinçlenmesinin de önü açlabilir.

Çalışmanın meslek ara elamanı yetiştiren meslek yüksekokullarındaki farklı programlardaki öğrencilere uygulanması, özellikle kariyer beklentileri açısından Meslek 
Yüksekokullarındaki öğrencilerin güncel durumu hakkında da fikir verebilir. Böylelikle mezun olacak öğrencilere kariyer planlamaları konusunda destek olunmasına olanak sağlanabilir. İlerleyen yıllar için ise, farklı programlarda okuyan öğrencilerin beklentilerindeki farklılıklara göre eğitim ve kariyer konusunda bazı yenilikçi adımların atılması mümkün olabilir. Aynı zamanda gelecek genç nesil içinde eksikliklerin görülerek, bir takım kariyer ve eğitim olanaklarının geliştirilmesi açısından ilgili kesimlere katkı sağlayabilir.

Araştırmada kullanılan ölçeklere başka ölçekler de eklenerek sonuçlar ve öğrencilerle ilgili yorumların kapsamı genişletilebilir.

Özetle ifade edilebilir ki, öğrencilerin kariyer beklentileri ve duygusal beklenti düzeyleri okudukları sınıfa, bölüme, okudukları bölümleri isteyerek tercih edip etmemelerine göre farklılık gösterebilmektedir. Araştırma kapsamının ilerleyen zamanlarda büyütülerek farklı üniversitelerdeki farklı öğrenim seviyesindeki öğrencilere kıyaslama yapılarak uygulanması, elde edilen bulguların daha sağlıklı hale gelmesine katkı sağlayacak ve kariyer, mesleki beklenti gibi konularla ilgili kesimlere de daha fazla ışık tutacaktır.

\section{Kaynakça}

Aktaş, E., Şahin, C. (2019). Üniversite Öğrencilerinin Kariyer Sürecinde Yaşadıkları Kariyer Kararsızlığının İncelenmesi. 21. Uluslararası Psikolojik Danışma ve Rehberlik Kongresi, Antalya.

Altunışık, R., Çoşkun, R., Bayraktaroğlu S., ve Yıldırım, E. (2012). Sosyal Bilimlerde Araştırma Yöntemleri. Sakarya Yayıncılık, Sakarya.

Atik, G. ve Yalçın, İ. (2010). Counselingneeds of educational, sciencesstudents at the Ankara University. Procedia Socialand Behavioral Sciences, 2, 1520-1526.

Baldıran, Ş. ve Şimşek, E. (2018). Meslek Yüksekokulundan Mezun Kadınların Okul Başarı Durumları İle Mezuniyet Sonrası Çalışma Durumlarının Karşılaştırılması: Amasya Meslek Yüksekokulu Örneği, Türk Turizm Araştırmaları Dergisi, Cilt 2, Sayı 4, 41-56.

Chircu, S. (2013). Careercounselingneedsforstudents - a comparativestudy. Procedia Socialand Behavioral Sciences, 127, 549 - 553.

Çakır, M., A. (2007). Mesleki Rehberlik. (Ed: Alim Kaya). Anı Yayıncılık, Ankara.

Dicleli, Z. ve Çetinbakış, M. (2004). Harvard Business Review Kariyer Yönetimi, Çeviri Kitabı. Türkiye Metal Sanayicileri Sendikası, BZD Yayın, Acar Matbaacılık, İstanbul.

Dörtyol, B. G. (2017). Tıp Fakültesi Son Sınıf Öğrencilerinin Mezuniyet Sonrası ile İlgili Düşünceleri, Kariyer Seçimleri ve Etkileyen Faktörler, Tıp Ĕ̆itimi Dünyası, Eylül-Aralık 2017, Sayı 50, 12-21.

Durmuş, B., Yurtkoru, S. ve Çinko, M. (2013). Sosyal Bilimlerde Spss'le Veri Analizi. Beta Basım A.Ş. 5. Bask1. İstanbul.

Erdoğmuş, N. (2003). Kariyer Geliştirme Kuram ve Uygulama, Nobel Yayın Dağıtım, Ankara. 
Fidan, T., Fidan, İ. Ö. ve Öztürk H. (2018). Meslek Yüksekokulu Öğrenci ve Mezunlarının Kariyer Seçimlerine Etki Eden Faktörler ile Kariyer Beklentileri: Öz Yeterliğin Aracı Rolü, Yükseköğretim Dergisi, 8(3): 249-263.

Gerçek, M. (2018). Mesleki Kaygı ve Kariyer Uyumluluğu Arasındaki İlişkiler: Öğretmen Adayları Açısından Bir İnceleme, Trakya Üniversitesi Sosyal Bilimler Dergisi, Cilt 20, Sayı 2, (297-312).

Greenhaus, J.H. (1987). Career Management. Dryden Press, New York.

Günay, İ. ve Akıncı, Z. (2017). Turizmde Sürdürülebilirlik Açısından Öğrencilerin Sektöre Karşı Tutumlarının Mezuniyet Sonrası Kariyer Planlaması ve Seçimine Etkisi, Mehmet Akif Ersoy Üniversitesi Sosyal Bilimler Enstitüsü Dergisi, Cilt 9, Sayı 20, 1-19.

İçerli, L., ve Arsu, Ş. U. (2019). Beş Faktör Kişilik Özelliklerinin Kariyer Değerleri Üzerindeki Etkisi: Üniversite Öğrencileri Üzerine Bir Araştırma, İktisadi İdari ve Siyasal Araştırmalar Dergisi, 4(8): 21-45.

Ilgar, E. A. ve Cihan, B. B. (2019). Spor Yöneticiliği Programlarında Öğrenim Gören Öğrencilerin Sektörel Beklenti, Mesleki Belirsizlik ve Gelecek Kaygılarının İncelenmesi: Fenomonolojik Bir Çözümleme, Spor Eğitim Dergisi, Cilt 3, Sayı 1, 81-92.

Karataş, A. ve Gizir, C. A. (2013). Üniversite öğrencilerinin psikolojik danışma ihtiyaçlarının çeşitli değişkenler açısından incelenmesi. Hacettepe Üniversitesi Eğitim Fakültesi Dergisi, 28(3), 250-265.

Kaval, U., Gökoğlan, K. (2020). Üniversite Öğrencilerinin Kariyer Eğilimleri: Dicle Üniversitesi Örneği. Dicle Üniversitesi İktisadi ve İdari Bilimler Fakültesi, Cilt 10, Sayı 19, 248 260.

Kılıç, Ö., U. (2018). Üniversite Son Sınıf Öğrencilerinin Kariyer Kararı Verme Yetkinliği Düzeylerini Etkileyen Değişkenler. Uluslararası Toplum Araştırmaları Dergisi, 9(16), 250275.

Kılınç, Y. ve Ateş, M. (2014). Coğrafya Lisans Öğrencilerinin Mezuniyet Sonrası Kariyer Planlarına İlişkin Görüşleri. Marmara Coğrafya Dergisi, Sayı: 29, S. 434-449

Köroğlu, Özlem. (2014). Meslek Seçimi İle Kişilik Özellikleri Arasındaki İlişkinin Belirlemesi: Turizm Rehberliği Öğrencileri Üzerine Bir Araştırma. Süleyman Demirel Üniversitesi İktisadi ve İdari Bilimler Fakültesi Dergisi, Y.2014, Cilt 19, Say1 2, 137-157.

Kuzgun, Y. (2009). Meslek Rehberliği ve Danışmanlığına Giriş. Nobel Yayınevi, Ankara.

Küçükoğlu M., Baynazoğlu, M.E., Berber Ş. (2020). Meslek Yüksekokulu Öğrencilerinin Kariyer ve Girişimcilik Yönelimleri, Manisa Celal Bayar Üniversitesi İ.̇.B.F Yönetim ve Ekonomi, Cilt 27, Say1 1, 91-108.

Nowakowski, C. (2002). Careerplanningneeds of students (Yayınlanmamış Doktora Tezi). Western Michigan University, USA. AĞUSTOS 2020 tarihinde https://scholarworks. wmich.edu/cgi/viewcontent.cgi?article=2298\&context=dissertations adresinden erişildi.

Owen, F., K. (2018). Üniversite Öğrencilerinin Kariyer Gelişim İhtiyaçları. Yaşadıkça Eğitim Dergisi, Cilt 32, Sayı 2, 28-39. 
Özden, Cemil. (2008). Kariyer Planlaması ve Yönetimi. Ödül Yayınları, İstanbul.

Öztemel, Kemal. (2012). Kariyer Kararsızlığı ile Mesleki Karar Verme Öz Yetkinlik ve Kontrol Odağı Arasındaki İlişkiler. GEFAD / GUJGEF 32 (2): 459-477.

Serdar, A., Baştürk, Ş., Arabacı, Ö. ve Baştaymaz, T. (2013). Üniversite Öğrencileri Arasında İsssizlik Riski, Kariyer Beklentileri ve Siyasal Marjinalleşme. Sosyal Siyaset Konferansları / Journal of SocialPolicy Conferences, Sayı:64-65 - 2013/1-2, 1-34.

Sevimli, F. ve İşcan, Ö.,F. (2005). Bireysel ve İş Ortamına Ait Etkenler Açısından İş Doyumu. Ege Akademik Bakış Dergisi, 5(1), 55-64.

Süer, E., Baklaci, H. F. ve Kocaer E. (2017). Para Tutumunun Kariyer Hedefleri Üzerindeki Etkisi: Üniversite Öğrencileri Üzerinde Bir Araştırma, Ege Akademik Bakış Dergisi, Cilt 17, Say1 4, 527-537.

Tuncer, Murat (2011). Yükseköğretim Gençliğinin Gelecek Beklentileri Üzerine Bir Araştırma. International PeriodicalfortheLanguages, LiteratureandHistory of Turkish of Turkic, V.6/2, 935-948.

Yerin, G. O., Owen, D.W., Tanrikulu, İ., Dolunay, C. F. ve Büyükgöze, K. A. (2016). Eğitim Fakültesi öğrencilerinin kariyer gelişimi ihtiyaçlarının incelenmesi. Eğitimde Kuram ve Uygulama, 12(1), 178-193.

Yeşilyaprak, B. (2018). Mesleki Rehberlik ve Kariyer Danışmanlığı Kuramdan Uygulamaya. Pegem Akademi, Ankara.

Zunker, V. G., Osborn, D. (2002). Using assessment results for career development. California: Pacific Grove, CA: Brooks/Cole.

\section{Açıklamalar}

Çalışmada 2020 yılı öncesi araştırma verileri kullanılmış olduğu için Etik Kurul İzin Belgesi alınmamıştır. 